$5-2005$

\title{
Ronan Point Apartment Tower Collapse and its Effect on Building Codes
}

Cynthia Pearson

Cleveland State University

Norbert Delatte

Cleveland State University, n.delatte@csuohio.edu

Follow this and additional works at: https://engagedscholarship.csuohio.edu/encee_facpub

Part of the Civil Engineering Commons, and the Structural Engineering Commons

How does access to this work benefit you? Let us know!

\section{Publisher's Statement}

(c) ASCE

\section{Original Citation}

Pearson, C., and Delatte, N. (2005). "Ronan Point Apartment Tower Collapse and its Effect on Building Codes." J.Perform.Constr.Facil., 19(2), 172-177.

This Article is brought to you for free and open access by the Civil and Environmental Engineering at EngagedScholarship@CSU. It has been accepted for inclusion in Civil and Environmental Engineering Faculty Publications by an authorized administrator of EngagedScholarship@CSU. For more information, please contact library.es@csuohio.edu. 


\title{
Ronan Point Apartment Tower Collapse and its Effect on Building Codes
}

\author{
Cynthia Pearson ${ }^{1}$ and Norbert Delatte, M.ASCE ${ }^{2}$
}

\begin{abstract}
In the early morning hours of May 16, 1968, the occupant of apartment 90 on the 18th floor of the 22-story Ronan Point apartment tower, in London, lit a match to brew her morning cup of tea. The resulting gas explosion initiated a partial collapse of the structure that killed four people and injured 17 (one of whom subsequently died). On investigation, the apartment tower was found to be deeply flawed in both design and construction. The existing building codes were found to be inadequate for ensuring the safety and integrity of high-rise precast concrete apartment buildings. The Larsen-Nielson building system, intended for buildings with only six stories, had been extended past the point of safety. The tower consisted of precast panels joined together without a structural frame. The connections relied, in large part, on friction. The apartment tower lacked alternate load paths to redistribute forces in the event of a partial collapse. When the structure was dismantled, investigators found appallingly poor workmanship at the critical connections between the panels. Subsequently, building codes in many countries have adopted structural integrity or "robustness" provisions that may be directly traced to the Ronan Point collapse.
\end{abstract}

CE Database subject headings: Structural failures; Building codes; Forensic engineering; Collapse; Case reports.

\section{Introduction}

In the early morning hours of May 16, 1968, the occupant of apartment 90 on the 18th floor of the 22-story Ronan Point apartment tower lit a match for her stove to brew her morning cup of tea. The resulting gas explosion, due to a leak, knocked her unconscious.

The pressure of the small gas explosion blew out the walls of her apartment, and initiated a partial collapse of the structure that killed four people and injured 17. One of the injured, an 82-yearold woman, subsequently died, but possibly not due to the collapse (Griffiths et al. 1968). The partially collapsed structure is shown in Fig. 1. The floor plan for apartment 90 is provided in Fig. 2.

The collapse was investigated and a report was quickly issued (Griffiths et al. 1968). The collapse was attributed to the gas explosion displacing walls and initiating a progressive collapse upward and then downward through the corner of the building. The building was repaired and reinforced. Years later, when the building was systematically dismantled, poor workmanship was found throughout. The Ronan Point collapse illustrated a lack of provisions for general structural integrity (or, as termed in the United Kingdom, "robustness") in existing building codes and led to changes in the United Kingdom, the United States, and Canada.

\section{Design and Construction}

In the decades following the Second World War, many high-rise apartment tower blocks were constructed in London to replace the housing stock destroyed during the conflict. A change in policy allowed the density of occupancy to increase substantially. Skilled construction laborers were also becoming scarce. This shortage worsened as construction workers began to take safer and easier jobs in factories (Bignell 1977).

These factors and the development of prefabricated construction techniques (known as system building) led to the popularity of high-rise apartment buildings. This new style of housing was intended to accommodate large numbers of people, save land and labor, and be constructed quickly.

The Ronan Point Apartment Tower was constructed using the Larsen-Neilsen system. This system was developed in Denmark in 1948. The Larsen-Nielson system was "composed of factorybuilt, precast concrete components designed to minimize on-site construction work. Walls, floors and stairways are all precast. All units, installed one-story high, are load bearing" (ENR 1968). This building system encompassed the patterns for the panels and joints, the method of panel assembly, and the methods of production of the panels.

Ronan Point was one of many identical high-rise precast concrete flat-plate structures constructed during this time. In this type of structural system, each floor was supported by the load-bearing walls directly beneath it. Gravity load transfer occurred only through these load-bearing walls. The wall and floor panels fitted together in slots. These joints were then bolted together and filled 


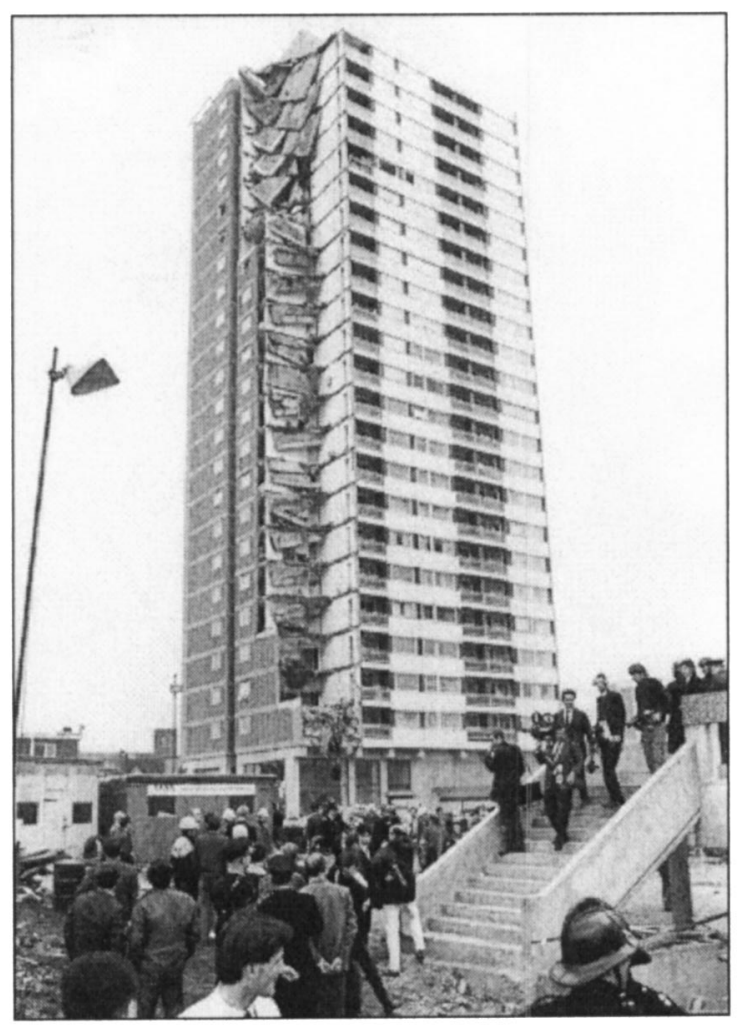

Fig. 1. Ronan Point after collapse

with dry-pack mortar to secure the connection. The connections are shown in Figs. 3 and 4.

Ronan Point was 22-stories tall. There were a total of 110 apartment units in the building, grouped five to a floor. The building had 44 two-bedroom apartments and 66 one-bedroom apartments. Construction began on Ronan Point on July 25, 1966, and the tower was completed on March 11, 1968 (Cook 2003). The building was near full occupancy.

\section{Collapse}

The southeast corner of the Ronan Point Tower collapsed on May 16, 1968, at approximately 5:45 a.m. The fatality rate could have been considerably higher than four people given the extent of the structural damage (Feld and Carper 1997). Fortunately, at the time of the disaster, all of the residents but one were sleeping in their bedrooms. The collapse sheared off the living room portion of the apartments, leaving the bedrooms intact with the exception of floors 17-22, where all the fatalities occurred. This corner of the building contained the only three vacant apartments left in the building. The apartment on floor 22 was the only one occupied above floor 18 .

The collapse was initiated by a gas-stove leak on the 18th floor in apartment 90. The resident struck a match and was knocked unconscious by the resulting explosion. The force of the explosion knocked out the opposite corner walls of the apartment. These walls were the sole support for the walls directly above. This created a chain reaction in which floor 19 collapsed, then floor 20, and so on, propagating upward. The four floors fell onto level 18, which initiated a second phase of the collapse. This sudden-impact loading on floor 18 caused it to give way, smashing floor 17 and progressing until it reached the ground.

\section{Government Investigation}

Pressured by the public, the government quickly formed a panel to investigate the collapse. The panel's report was issued later that year (Griffiths et al. 1968). It was quickly determined that the explosion from the gas leak had initiated the collapse of the building. A substandard brass nut had been used to connect the hose to the stove. The nut had a thinner flange than the standard, and also had an unusual degree of chamfer. A replicate of this nut was made and tested to determine how much force was required to break it.

It was found that a force of $15.6 \mathrm{kN}(3,500 \mathrm{lbs})$ would break the connection. It was also concluded that the hose connecting the stove to the gas line would have failed before the nut, at a force of $1.6 \mathrm{kN}$ (360 lbs). The nut was assumed to have been previously fractured by overtightening during installation, causing it to break and allowing gas to leak into the apartment (Griffiths et al. 1968).

The gas may have accumulated at the ceiling, explaining why the resident did not notice it. The explosion was not significant in magnitude. The resident's hearing had not been damaged. This suggested that the pressure was less than $70 \mathrm{kPa}(10 \mathrm{psi})$ (Bignell 1977). Items were taken from the kitchen of this apartment and tested. Results indicated that these objects had been exposed to pressures of less than $70 \mathrm{kPa}(10 \mathrm{psi})$.

The Building Research Station and Imperial College of London performed an extensive battery of tests to discover how much internal force Ronan Point could withstand. The results indicated that the walls could be displaced by a pressure of only $19.3 \mathrm{kPa}$ (2.8 psi) (Levy and Salvadori 1992). It was estimated that the kitchen and living room walls were moved by a pressure of only $1.7 \mathrm{kPa}(0.25 \mathrm{psi})$, while the exterior wall was displaced with a pressure of $21 \mathrm{kPa}$ (3 psi) (Griffiths et al. 1968).

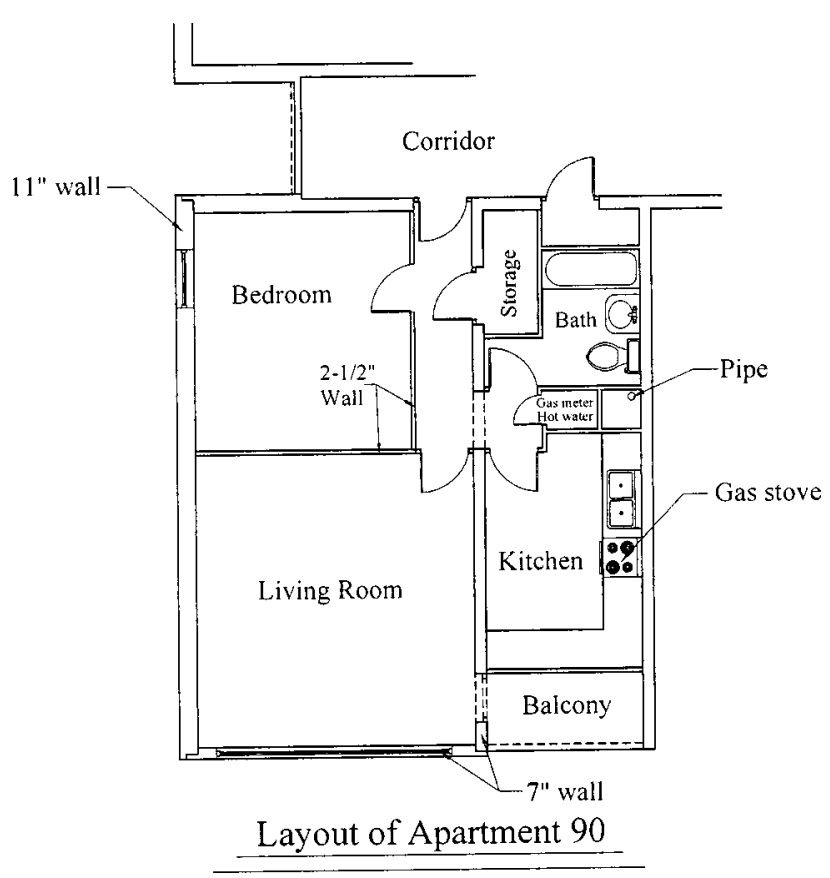

Fig. 2. Floor plan of apartment (based on Bignell [1977] and Levy and Salvadori [1992]) 


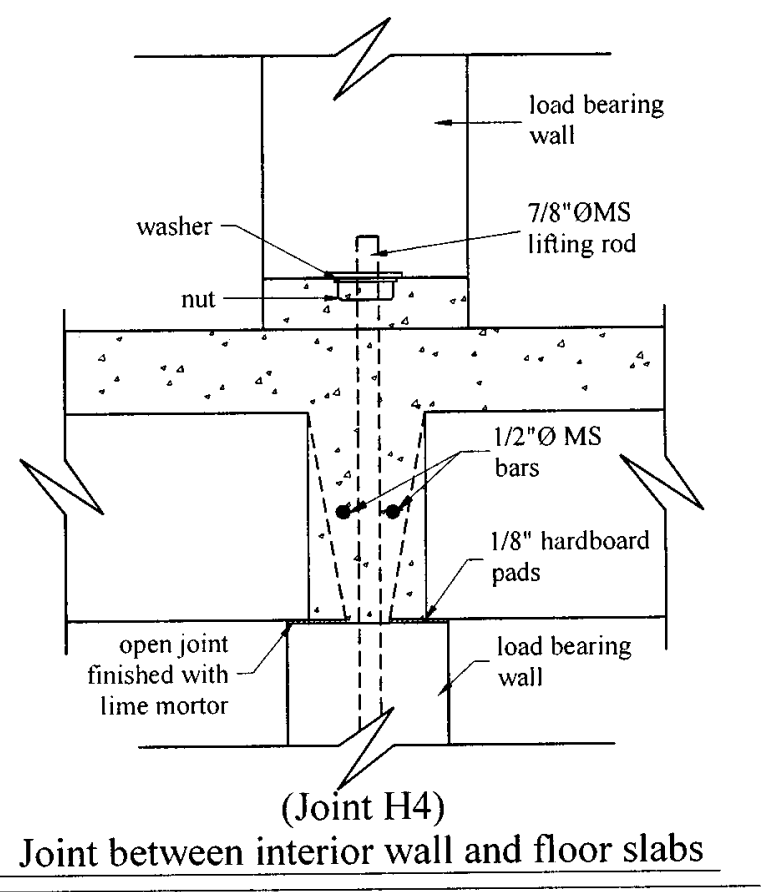

Fig. 3. Interior joint (based on Wearne [2000], Bignell [1997], and Levy and Salvadori [1992])

Ultimately, the collapse of Ronan Point was due to its lack of structural redundancy. Its design did not incorporate fail-safe mechanisms, and provided no alternative load paths for the upper floors should a lower level give way.

\section{Remedial Actions}

The southeast corner of Ronan Point was rebuilt as a separate section of apartments and then joined to the existing building by means of walkways. Ronan Point was reinforced with blast angles as part of the reconstruction. The blast angles added are shown in Fig. 4, on the right side. Gas was also banned from Ronan Point.

\section{Technical Aspects}

Several factors became apparent after the public inquiry into the collapse. The investigation revealed that strong winds and/or the effects of a fire in the building could also have caused a progressive collapse. Ronan Point was designed to withstand wind velocities of only $100 \mathrm{kph}(63 \mathrm{mi} / \mathrm{h})$, but later research indicated that for buildings of that height higher wind velocities could be expected.

The building code used for the design of Ronan Point and its sister buildings was issued in 1952. This set of codes had not been kept up to date. Higher winds than those listed in the building code were known to occur based on a publication in 1963 by the National Physical Laboratory (Griffiths et al. 1968). It was noted that "the structure had been designed to comply with fifteen-yearold wind load codes that did not take into account current building heights" (ENR 1970). According to the inquiry, "the suction effect of the pressures applied by such winds, in particular the opening of the joints as the tower block bent in the wind, would have similar effect to the explosion."

Fire might have also led to a collapse of Ronan Point. The inquiry stated, "it is estimated that fire could so expand and 'arch' the floor slab and bend the wall panel, as to displace or rotate an H-2 joint to a dangerous degree" (Wearne 2000).

\section{Sam Webb, Whistleblower}

An architect named Sam Webb developed an interest in Ronan Point. He predicted that after approximately 15 years of service, Ronan Point would develop serious structural problems, especially with the joints. In a conversation with some tenants of Ronan Point he predicted, "there would be gaps between walls and floors through which smoke would pass ... you'd be able to hear people and their televisions on different floors" (Wearne 2000).

Some of the residents invited him into their apartments to perform tests. According to Webb: "One of the simplest tests was to get a sheet of paper, tear a strip off, put it against the skirting board, and let it go at one end. The loose end was coming out at ceiling level in the apartment below. Another basic test was to put a coin up against the wall and let it go. It fell through the gap as if going into a slot machine" (Wearne 2000).

The chair of Newham's housing committee asked Webb to conduct a survey to assess the condition of the building. Webb and a team of architectural students surveyed nearly half of Ronan Point's 110 apartments. Their findings revealed cracks in the central stairwell and elevator shaft, which indicated movement throughout the building. After analyzing the cracks, Webb realized that his predictions about Ronan Point had been confirmed. He concluded, "In high winds it was beginning to break up." The building "was moving on its lifting bolts and was held up by the 'blast angles' fitted after the public inquiry. The drypack mortar had been crushed-or was never there in the first place" (Wearne 2000). A fire test was conducted 16 years after the collapse of the southeast corner, which verified the building's vulnerability to fire.

\section{Demolition of Ronan Point}

Continuing concerns over the building's structural integrity eventually led to its demolition in May of 1986. This type of building had a life expectancy of 60 years, but Ronan Point was razed after just 18 years of service. The building was not demolished in the traditional fashion. Instead, Ronan Point was dismantled floor-byfloor so that the joints could be studied. The site was an "open site" for anyone interested.

A shocked Webb commented: "I knew we were going to find bad workmanship-what surprised me was the sheer scale of it. Not a single joint was correct. Fixing straps were unattached; leveling nuts were not wound down, causing a significant loading to be transmitted via the bolts; panels were placed on bolts instead of mortar. But the biggest shock of all was the crucial H-2 loadbearing joints between floor and wall panels. Some of the joints had less than fifty percent of the mortar specified" (Wearne 2000). Wearne (2000) provides a complete account of Webb's work investigating Ronan Point.

The findings of the poor workmanship in the construction of Ronan Point led to the demolition of the remaining LarsenNielson system-built towers. At the time these buildings were erected, the building codes did not adequately address them. Large concrete-panel construction was the height of innovation at this time, and little was known about how it would perform. The 

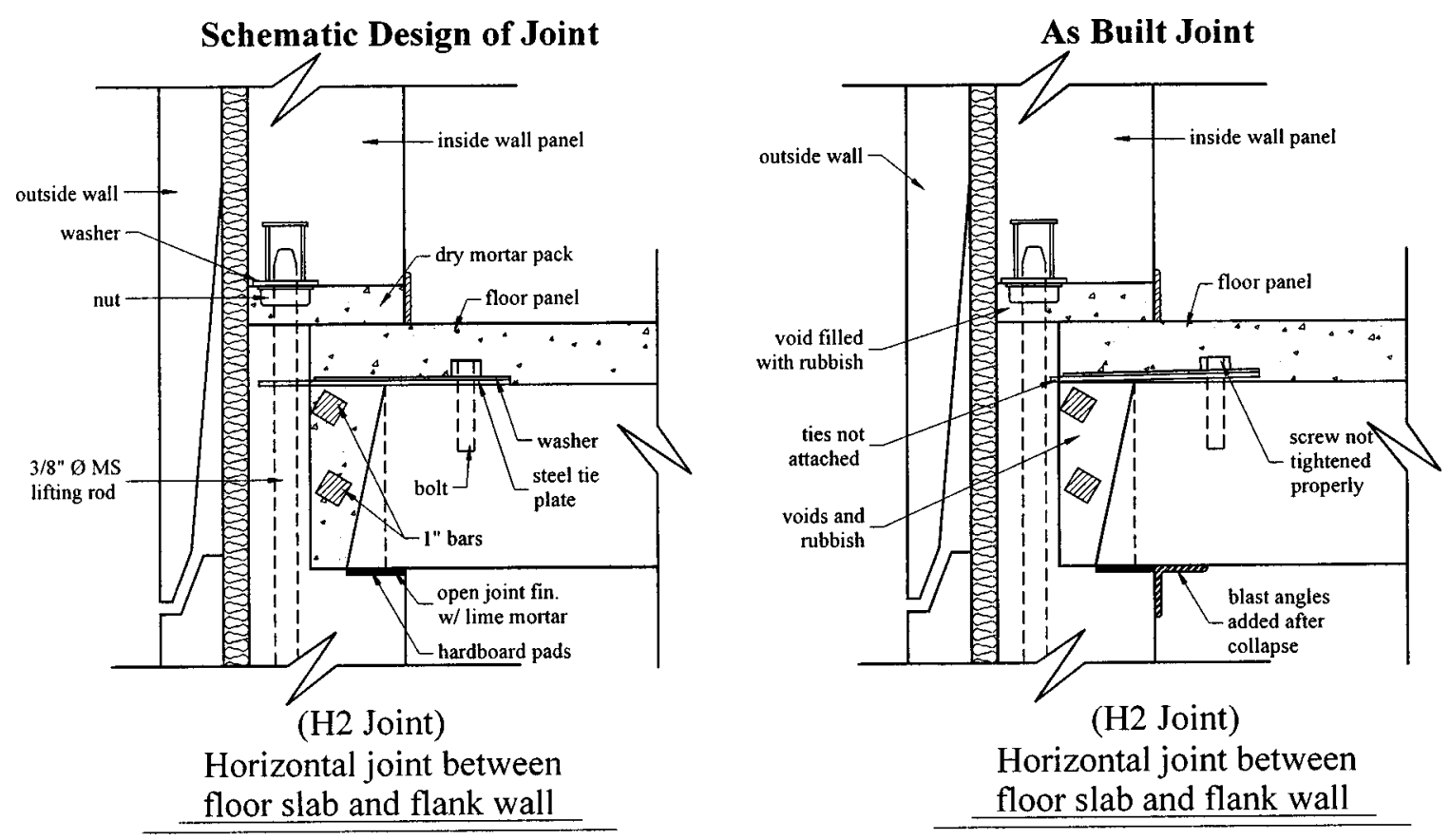

Fig. 4. Exterior joints (based on Wearne [2000], Bignell [1997], and Levy and Salvadori [1992])

building regulations in effect at the time contained a "catch-all" clause known as the "functional requirement on structure." This clause contained no mention of redundancy or progressive collapse (Bignell 1977).

\section{Changes to Building Codes}

It was concluded by the inquiry that the codes governing construction and design methods needed immediate reevaluation. The authors of the inquiry stated in their report: "[W]e do not consider that in its present form Ronan Point is an acceptable building, and yet it was designed to comply with the statutory standards contained in the Newham by-laws, which are, in all material respects, identical with current Building Regulations. This is so manifestly an unsatisfactory state of affairs that it is necessary to enquire how it came about and to consider remedies for the future" (Griffiths et al. 1968).

The collapse of the southeast corner of Ronan Point initiated changes to building codes. Building codes now take into account the possibilities of progressive collapse and of forces from an internal explosion. The codes also require minimum amounts of ductility and redundancy.

One of the outcomes of this inquiry was the development of the "fifth amendment" to the U.K. building regulations in 1970. According to Hendry, "[it] applies to all buildings over four stories and requires that under specified loading conditions a structure must remain stable with a reduced safety factor in the event of a defined structural member or portion thereof being removed. Limits of damage are laid down and if these would be exceeded by the removal of a particular member, that member must be designed to resist a pressure of $34 \mathrm{kN} / \mathrm{m}^{2}\left(51 \mathrm{lb} / \mathrm{in}^{2}\right)$ from any direction. Of special importance in relation to load bearing wall structures is that these conditions should be met in the event of a wall or section of a wall being removed, subject to a maximum length of 2.25 times the story height" (Hendry 1979).

The British conducted research on progressive collapse. The
British government mandated guidelines for the prevention of progressive collapses. These instructions included the requirement of a fail-safe mechanism in all large panel-system buildings, steel bracing with floor-to-wall connectors, and a minimum tensile strength of $21 \mathrm{MPa}(3,000 \mathrm{psi})$ across the length and width of the roofs and floors (ENR 1970).

The lessons from Ronan Point changed building regulations throughout the world. The United States followed and also implemented new design criteria (Fuller 1975). The Portland Cement Association and the Prestressed Concrete Institute also issued guidelines, including "tying building elements together and increasing ductility so that the building elements can better sustain deformations from the failure of a portion of the building's structure. Transverse ties create cantilever action from adjacent walls. Vertical ties provide suspension from panels above, peripheral ties hold floors together, and longitudinal ties string floor plankslarge prestressed panels-together" (Ross 1984).

The engineering profession was reminded of the need for redundancy in design to prevent a progressive collapse. It is of utmost importance that building designs contain some measure of continuity (Shepherd and Frost 1995).

Over 25 years after the collapse, Longinow and Ellingwood (1998) detailed the impact of the Ronan Point incident on building codes. Changes made to U.S. model codes, particularly the "Basic Building Code" (BOCA 1996), as well as to the National Building Code of Canada (CCBFC 1995), provided for structural integrity. The ASCE standard SEI/ASCE 7-02 "Minimum design loads for buildings and other structures" (formerly American National Standards Institute ANSI A58) contains section 1.4 providing for general structural integrity. It requires that structures "shall be designed to sustain local damage with the structural system as a whole remaining stable" (ASCE 2002). Kaminetzky (1991) notes that the New York City and Connecticut building codes also incorporated structural integrity provisions based on the Ronan Point incident.

For reinforced concrete structures, the American Concrete Institute (ACI) code provides for structural integrity in chapters 7 
(Details of Reinforcement), 13 (Two-Way Slab Systems), 16 (Precast Concrete), and 18 (Prestressed Concrete) (ACI 2002). These provisions require the designer to tie the structure together and provide capacity in the case of moment reversal (Cagley 2003).

The concept of quality control in the construction process was reinforced after the dismantling of Ronan Point. Although the design flaw was the main downfall of Ronan Point, poor construction quality exacerbated problems with the building's structural integrity.

Quality control must be enforced in the construction process to ensure public safety. According to Feld and Carper (1997), "As with all other construction materials, the best designs in precast and prestressed concrete can be ineffective unless the work done in the field is of high quality. If the design is marginal, construction deficiencies can compound the errors increasing the potential for serious problems.... Skilled supervisors who understand the design intent and can communicate it clearly to the field workers are needed full-time at the construction site while all prestressed concrete work is erected" (Feld and Carper 1997).

\section{Ethical Aspects}

Substandard workmanship had been detected in the initial inquiry of the collapse. However, this information was hidden from the public. Was it a question of ethics or politics? By the time the inquiry's findings were published in 1968, many large panelconcrete buildings had been completed. The government did not want to consider demolishing these buildings. At least six LarsenNielson system buildings had been completed by this time. There was not enough money to strengthen them. Did the government endanger the lives of the residents of these facilities by taking only minimal action to strengthen the buildings?

\section{Educational Aspects}

There are many lessons to be learned from this case. This is an excellent example of what could happen when alternative load paths are not provided. Structural integrity against progressive collapse, or "robustness," should be taught in engineering schools. Longinow and Ellingwood (1998) note that in the decade after the Ronan Point incident, over 300 engineering articles and reports were published on the topic and European countries and Canada had adopted standards, but that research had stalled and more work was needed.

\section{Summary and Conclusions}

The investigations found that the Ronan Point apartment tower was deeply flawed in both design and construction. The existing building codes were inadequate for ensuring the safety and integrity of high-rise precast concrete apartment buildings. In particular, the design wind pressures were too low and did not account for the height of the building. The Larsen-Nielson building system, intended for buildings with only six stories, had been extended past the point of safety.

The tower consisted of precast panels joined together without a structural frame. The apartment tower lacked alternate load paths to redistribute forces in the event of a partial collapse. When the structure was dismantled, investigators found appallingly poor workmanship of the critical connections between the panels. The structure had been further weakened by the inadequate construction practices. The result was described by Levy and Salvadori (1992) as a "house of cards."

The relatively low overpressure from the gas explosion should have led to localized damage at most, not a partial progressive collapse and the loss of four lives. The evaluation also found that the building was unusually vulnerable to ordinary wind and fire loading.

Technology should never be counted on to substitute for properly supervised skilled labor. There is a risk to the public when pre-engineered structural systems are used without adequate consideration of the requirements of the project at hand, particularly when the use of the system is expanded well beyond the original intention. Fortunately, many building codes have developed provisions to guard against similar failures.

\section{Acknowledgments}

Support for this research was provided by the National Science Foundation under the project "Developing Case Studies in Failures and Ethics for Engineering Educators," project number DUE 0127419.

\section{References}

American Concrete Institute (ACI). (2002). "Building code requirements for structural concrete," and "Commentary." $A C I$ 318-02 and $A C I$ 318R-02, ACI, Farmington Hills, Mich.

ASCE. (2002). "Minimum design loads for buildings and other structures." SEI/ASCE 7-02, Reston, Va.

Bignell, V., Peters, J., and Pym, C. (1977). Catastrophic failures, Open University Press, Milton Keynes, N.Y.

Building Officials and Code Administrators International, Inc. (BOCA). (1996). "The BOCA Basic/National Building Code," BOCA, Falls Church, Va.

Cagley, J. R. (2003). “The design professional's concerns regarding progressive collapse design." National Institute of Building Sciences, 〈http://www.nibs.org/MMC/ProgCollapse\%20presentations/ Cagley\%20paper.pdf $\rangle$ (October 7, 2003).

Cook, L. (2005). "Events in local history-Ronan Point 1968." 〈http:// www.lalamy.demon.co.uk/ronanpnt.htm〉 (February 26, 2005).

Eng. News-Rec. (ENR). (1968). "Systems built apartments collapse." May 23, 23.

Eng. News-Rec. (ENR). (1970). "Britain tightens building standards, moves to stem 'progressive collapse.'” April 16, 12.

Feld, J., and Carper, K. (1997). Construction failure, Wiley, New York.

Fuller, R. (1975). "Industrialized concrete construction for HUD." Industrialization in concrete building construction, American Concrete Institute, Detroit.

Griffiths, H., Pugsley, A. G., and Saunders, O. (1968). "Report of the inquiry into the collapse of flats at Ronan Point, Canning Town." Her Majesty's Stationery Office, London.

Hendry, A. W. (1979). "Summary of research and design philosophy for bearing wall structures." J. Am. Concr. Inst., 76(33), 723-737.

Kaminetzky, D. (1991). Design and construction failures: Lessons from forensic investigations, McGraw-Hill, New York.

Levy, M., and Salvadori, M. (1992). Why buildings fall down, Norton, New York.

Longinow, A., and Ellingwood, B. R. (1998). "The impact of the Ronan 
Point collapse-25 years after." Structural Engineering World Wide 1998, Paper Reference P312-2, Elsevier Science, New York.

Canadian Commission on Building and Fire Codes (CCBFC). 1995. "National building code of Canada." National Research Council of Canada, Ottowa.

Ross, Steven (1984). Construction disasters: Design failures, causes, and prevention, Eng. News-Rec., McGraw-Hill, New York.

Shepherd, R., and Frost, J. D. (1995). Failures in civil engineering, structural, foundation and geoenvironmental case studies, ASCE, New York.

Wearne, P. (2000). Collapse: When buildings fall down, TV Books, New York. 